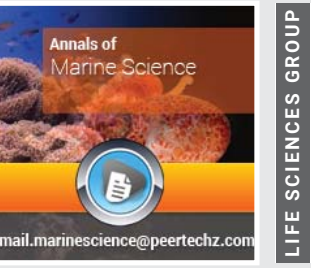

\title{
Traumatism during mooring operations on vessels
}

\section{Shapovalov KA* and Shapovalova PK}

State Education Agency of Additional Professional Education of the Republic of Komi "Komi

Republican Institute for Development of Education" Syktyvkar, Republic of Komi, Russian Federation

Received: 17 September, 2019

Accepted: 28 May, 2020

Published: 29 May, 2020

*Corresponding author: Shapovalov KA, State Education Agency of Additional Professional Education of the Republic of Komi "Komi Republican Institute for Development of Education" Syktyvkar, Republic of Komi, Russian Federation, E-mail: stampdu@rambler.ru

Keywords: Mooring operations; Occupational injuries; Members of vessel's crew; Northern water basin

https://www.peertechz.com

(D) Check for updates

\section{Abstract}

Introduction: Mooring operations on modern vessels remain one of the least mechanized types of work. Mooring injuries are characterized by a particularly gross violation of soft tissues and bones.

Materials and methods: The analysis of the treatment of 224 patients from members of crew who received occupational injuries while mooring the vessels while performing voyages in the northern water basin. When working on the material, analytical and statistical methods were used. The significance of differences was calculated using Student's t-criteria for independent samples.

Results: In the structure of occupational injuries of members of vessel's crew of the Northern water basin, various injuries sustained during the mooring of vessels account for $10.1 \%$ of cases. In the Northern region, mooring injuries most often occur on transport river $(46.7 \%)$ and sea (36.3\%) ships, in which traffic is intensive, loading and unloading can occur at various berths within the same port, which increases the frequency of mooring operations during short transitions and, accordingly, the probability of mooring injuries. Outpatient treatment due to mooring injuries received $50.8 \%$ of members of vessel's crew. The second half of the mooring injuries required emergency hospitalization, long-term treatment in the surgical department and further rehabilitation at the outpatient stage.

Discussion: Every tenth work-related injury sustained by of members of vessel's crew of the Northern water basin occurs during mooring operations. Compliance with the mooring technology of the vessel, the improvement of the materials from which the mooring ends are made and the development of automated mooring complexes are the main areas of technological reduction of mooring injuries. Preventive measures for the prevention of mooring injuries should be continuous systemic in nature and should concern not only the technical improvement of mooring mechanisms, but also the constant training of members of vessel's crew in safety techniques, first aid in case of injuries and health education.

\section{Conclusions:}

1. In the general structure of occupational traumatism of members of vessel's crew of the Northern water basin, various damages during the mooring of vessels account for $10.1 \%$ of cases.

2. The risk of mooring injuries is greatest in the transport river and sea fleets among sailors with production experience of up to 1 year of work in the specialty.

3. Mooring injuries are characterized by the predominance of severe bruises, deep wounds and traumatic amputations of the phalanges of the fingers.

4. The average period of incapacity for work with mooring injuries is 48.0 working days, the hospital bed for hospitalization in the surgical department - 20.6 .

5. Returned to professional work after rehabilitation for mooring injuries, $94.0 \%$ of the victims of members of vessel`s crew. The initial exit of victims to the II group of disability was $1.3 \%$; Group III $-2.2 \% ; 2.5 \%$ of mooring injuries were fatal.

\section{Introduction}

Mooring operations on modern ships remain one of the least mechanized types of work. The widespread introduction of automation practically did not affect the most frequent production operation performed by the deck crew. Most techniques for mooring a vessel are done manually. Mooring operations are the "center" of injuries on all floating equipment without exception [1]. In their production, a high frequency of bruises, wounds and bone fractures was established. The largest percentage of traumatism is injuries to the hands (58.6\%). The lower extremities are damaged in $35.2 \%$ of cases, the head and 
spine $-4.2 \%$. Only in mooring operations on fishing vessels, $8.0 \%$ of accidents occur $[2,3]$.

Mooring injuries are characterized by a particularly gross violation of soft tissues and bones. A damaging agent is often a steel cable that causes particularly serious injuries. With closed injuries, subcutaneous muscle ruptures, comminuted bone fractures, and extensive hemorrhages are observed [4-6]. Open damages are significant breaks and crushing of tissues or traumatic amputations of the extremities, which may result in the death of the victim $[7,8]$. Damage by a cable during mooring operations is most often associated with a violation of elementary rules of organization and conduct of work, as well as structural imperfection of mooring mechanisms. According to the literature, the average period of incapacity for work of sailors injured during mooring is 65 days, in especially severe cases - 180-205 days [9].

\section{Materials and methods}

The analysis of the treatment of 224 patients from members of vessel's crew who received occupational injuries while mooring the vessels while performing voyages in the Northern water basin.

When working on the material, methodological approaches were used: systemic, integrated, integration, functional, dynamic, process, normative, quantitative, administrative and situational. Analysis methods included: analytical and comparison. The methods used were: groupings, absolute and relative values, average values, detailing and generalization. The results were processed statistically on a personal computer. The arithmetic mean and standard deviation for the normal type of distribution of variables were used as the main characteristics of descriptive statistics. Qualitative signs were presented in the form of relative frequencies with the determination of the confidence interval. The significance of differences in quantitative characteristics between groups in the normal distribution of quantitative variables was calculated using Student's t-criteria for independent samples. The threshold error probability for statistically significant differences was set at 0.05 .

\section{Results}

In the structure of occupational injuries of members of vessel`s crew of the Northern water basin, various injuries sustained during the mooring of vessels account for $10.1 \%$ of cases. The average age of the victims was 28.2 years, among them men predominated - 97.3\% $(\mathrm{P}<0.001)$. Young sailors under 30 make up the main group of victims - $73.6 \%$ of observations. Other age groups have a small number of injuries: 30-39 years old and 40-49 years old $-9.4 \%$ each; 50 years and older $-7.6 \%$ (all differences are significant, $\mathrm{P}<0.001$ ).

In the Northern region, mooring injuries most often occur on transport river $(46.7 \%)$ and sea $(36.3 \%)$ vessels, where traffic is intensive, loading and unloading can occur at different berths within the same port, which increases the frequency mooring operations during short transitions and, accordingly, the probability of mooring injuries. Seafarers of the port fleet made up only $10.8 \%$ of the injured, fishing - $3.7 \%$, technical $-2.5 \%$. Representatives of the ship operation service reliably receive the majority of injuries during mooring operations (78.4\%; P<0.001).

Each member of the deck crew is assigned a regular place when mooring the vessel. Mooring operations on the tank are usually led by a third assistant captain, and aft by a second assistant. The bow and stern mooring mechanisms are controlled by the boatswain and the carpenter (senior sailor), respectively. The forthcoming mooring is warned in advance by the watch mechanic who prepares the car for work in maneuverable mode. Members of the deck crew, dressed in season, in shockproof helmets and mittens without fasteners, take their places according to the staffing list for mooring operations. The senior assistant to the captain is called to the bridge, the senior mechanic to the engine room $[10,11]$.

Half of the mooring injuries were received by sailors. Combining professions in water transport, engaging other shipboard specialists in mooring operations in difficult navigational conditions with a small number of crews determines a significant number of injured minders (19.4\%), navigators $(10.9 \%)$, skippers $(7.4 \%)$, boatswain $(3.7 \%)$, captains $(3.7 \%)$ and mechanics $(2.5 \%)$.

The highest level of traumatism was observed when mooring at sailors with a fleet experience of 1 to 6 months $26.4 \%$ of cases. It decreases more than three times in the next 6 months (7.4\%). Despite ongoing technical training, briefing, and injuries during this type of vessel's work after the first year of sailing, there is no downward trend. So, members of vessel's crew with a work experience of 5 to 10 years amounted to $21.8 \%$ of the victims, that is, slightly less than the newcomers who just arrived on water transport.

The mechanism of mooring injuries associated with work with hemp, dacron and steel cables. Light damage occurs when shifting cable bays. In this case, puncture wounds occur with damaged wires, abrasions and bruises. Sometimes there are also "burns" of palms and fingers when trying to hold a fast-moving cable with your hands. Damage is caused by blunt objects (98.7\%). With sailors, falls occur on a slippery deck with technically incorrect execution of production methods, including a fall from a height (6.2\%) [12].

The implementation of mooring works is especially affected by neuropsychic stress during the working week. So, if on Monday and Tuesday there are $10.7 \%$ and $8.5 \%$ of mooring injuries respectively, then on Thursday and Friday $14.4 \%$ and $21.6 \%$. The seasonal occurrence of mooring injuries in the northern basin was revealed. Most of them (74.5\%) occurred in the summer and autumn, which is explained by the maximum traffic in the basin during this period. In winter, it is minimal $-7.3 \%$, in spring it increases to $18.2 \%$.

During mooring operations, every fifth injury is accompanied by massive damage; polytrauma accounted for $19.5 \%$ of cases, among the latter multiple (93.4\%) and combined $(6.6 \%)$ prevailed. Polyfocal lesions within one anatomical and functional segment were identified in $28.7 \%$ of cases. 
Outpatient treatment due to mooring injuries was received by $50.8 \%$ of sailors. Every second injury required long-term treatment in the surgical department and further rehabilitation at the outpatient stage. $82.4 \%$ of the injured were delivered in the first 6 hours after the injury, and $91.3 \%$ on the first day. Thus, urgent qualified surgical care for mooring injuries is carried out in a timely manner, which leads to a favorable course of the hospital period and good outcomes of injuries. In the surgical department, members of vessel's crew are treated for the most severe mooring injuries, including: polytrauma - $48.9 \%$ or polyfocal injuries $-48.6 \%$. The nature of mooring injuries is presented in Table 1.

During mooring operations in members of vessel's crew, a significant increase in severe bruises, deep wounds, and traumatic amputations of the phalanges of the fingers was noted. The number of traumatic brain injuries is 1.6 times less; there are no combined injuries with burns and frostbite. Damage to the head during mooring is accompanied mainly by its bruises and closed head injuries: concussions of the brain. Among the mooring injuries of the upper limb, injuries to the hand is the most typical, they make up $39.6 \%$ of the total. If among them fractures of the bones of the hand remain the main type of damage, then traumatic amputations are as common as wounds (Table 2 ).

Bruises and dislocations of the hand are extremely rare. The forearm is injured 8.2 times less often than the wrist, and shoulder injuries during mooring operations during the study period were not noted. Damage to the clavicle, abdominal cavity, bones of the pelvis, spine, thigh, knee joint are represented by single observations. More common met chest injuries. They arise as a result of the fall of the floating train when working on a slippery deck or when the ends of the cable burst. Severe bruises or blunt chest injuries are accompanied by fractures of 1-3 ribs. The tibia is the second anatomical and functional formation after the hand, the most prone to injuries during mooring operations. Moreover, her bruises prevail over fractures and wounds. In third place is the foot, every second injury is accompanied by bone fractures. It should be noted that with mooring injuries, open fractures occur 1.4 times more often than the average in the basin.

Table 1: The structure of the general occupational and mooring traumatism of members of vessel's crew of the Northern water basin by the type of damage in \% $(\mathrm{P} \pm \mathrm{m})$.

\begin{tabular}{|c|c|c|}
\hline $\begin{array}{c}\text { Type of damage / Type of } \\
\text { traumatism }\end{array}$ & $\begin{array}{c}\text { Mooring } \\
\text { traumatism }\end{array}$ & $\begin{array}{c}\text { General occupational } \\
\text { traumatism }\end{array}$ \\
\hline Fractures & $36,8 \pm 2,7$ & $40,2 \pm 0,8$ \\
\hline Bruises & $24,6 \pm 2,4$ & $15,7 \pm 0,6$ \\
\hline Wounds & $21,0 \pm 2,3$ & $15,5 \pm 0,6$ \\
\hline Traumatic amputations & $11,1 \pm 1,8$ & $5,8 \pm 0,4$ \\
\hline Head injuries & $2,6 \pm 0,9$ & $4,3 \pm 0,3$ \\
\hline Dislocations & $1,3 \pm 0,6$ & $1,0 \pm 0,2$ \\
\hline Other species & $2,6 \pm 0,9$ & $11,4 \pm 0,5$ \\
\hline Burns & -- & $5,6 \pm 0,4$ \\
\hline Frostbite & -- & $0,5 \pm 0,1$ \\
\hline Total: & 100,0 & 100,0 \\
\hline
\end{tabular}

Table 2: The structure of mooring traumatism of the members of vessel's crew of the Northern water basin by type and anatomical and functional localization (in \%).

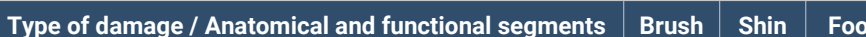

\begin{tabular}{|c|c|c|c|}
\hline General structure & 39,9 & 18,2 & 13,4 \\
\hline Bruises & 6,0 & 39,8 & 18,0 \\
\hline Wounds & 27,2 & 26,8 & 9,2 \\
\hline Fractures & 36,5 & 33,4 & 54,4 \\
\hline Traumatic amputations & 27,4 & -- & 9,2 \\
\hline Other species & 2,9 & -- & 9,2 \\
\hline Total:: & 100,0 & 100,0 & 100,0 \\
\hline
\end{tabular}

The average period of disability for mooring injuries was 48.0 working days, the hospital bed for hospitalization in the surgical department - 20.6. The outcomes with this type of pathology in water transport in $94.0 \%$ of cases are favorable. The initial exit of victims to the II group of disability was $1.3 \%$; Group III $-2.2 \% ; 2.5 \%$ of mooring injuries were fatal [13].

\section{Discussion}

Every tenth work-related injury sustained by members of vessel's crew of the Northern water basin occurs during mooring operations. The mooring device is the oldest of all used on the ship. It changed technically, but its purpose remained unchanged - to keep the ship at the mooring. Therefore, the process of setting a vessel to a berth, mooring barrels and other structures intended for the mooring of ships, as well as to another vessel, is called mooring. The departure of the vessel from the object to which it was moored is called unmooring $[11,14]$.

The term "mooring operations" should be understood as all the actions of crew members when mooring and unmooring the vessel. Mooring operations are one of the most critical and complex elements of a ship's voyage. For their high-quality implementation, it is necessary to know the maneuvering characteristics of the vessel well, take into account the situation at the berth (the presence and location of the ships) and external factors (direction and strength of the wind, flow, tidal phase, low tide, etc.).

The classic mooring of a vessel, which, for example, embarks on the port side to the berth, should have 8 mooring ends: 1) right nasal longitudinal; 2) left nasal longitudinal; 3) nasal pinch; 4) nasal spring; 5) feed spring; 6) feed presser; 7) left aft longitudinal; 8) right aft longitudinal [12,14]. That is, feeding from the shore to the shore eight mooring ends, taking these ends by the shore, planting them on the coastal guns and pulling are a multi-component practical action. Therefore, mooring operations with external simplicity are very complex and unpredictable. The slightest inaccuracies in the execution of the mooring mechanism of a vessel of technical or personal origin become the causes of occupational mooring traumatism.

The materials from which mooring ends are made are different. In modern practice, synthetic materials have replaced plant materials. The initially widely used kapron had to be abandoned because of its ability to absorb water and sink in it, 
poor bending at low temperatures and very strong stretching leading to a possible rupture. Currently, propylene, which does not have the disadvantages of kapron, is widely used. A new type of material - kevlar is very practical, but is afraid of contact with petroleum products and requires thoroughness when securing to mooring mechanisms, therefore it is used extremely rarely. On ships of large tonnage, steel ends are used, which, with the slightest damage, are especially dangerous for injuries to the fingers.

Trelleborg Company has developed an automated mooring complex that includes suction cups and a defender. It not only excludes manual labor while mooring the vessel, but also computerizes it. When the vessel is docked at the berth, unloading or loading takes place in the conditions of sea tides. Therefore, the watchmen supervise the mooring ends, periodically make rounds on the ship, and if necessary, weaken, or vice versa, pull the ends. The management of the mooring complex is fully computerized, there is an automatic control over the change in the draft of the vessel and other related phenomena. However, to date, the widespread wide spread use of an automated mooring complex has not received because of its high price [11 15].

Therefore, mooring operations remain one of the most nonmechanized types of vessel work performed by the deck crew exclusively by hand, and is a source of occupational injuries on board the vessel. Consequently, preventive measures for the prevention of mooring traumatism should be of a continuous systemic nature and should concern not only the technical improvement of mooring mechanisms, but also the constant training of members of vessel's crew in safety techniques, first aid in case of injuries and health education $[10,12]$.

The relevance of the prevention of mooring traumatism, the interest of campaign managers and each vessel's crew is confirmed by the attitude to medical information on the characteristics of the consequences of injuries during mooring operations on vessels of the northern water basin, prepared in 1986. An article on the prevention of mooring injuries from April 2 to October 18 was published and reprinted in the order of information exchange by corporate internal multi-circulation newspapers of seven fishing campaigns, two sea and seven river shipping companies [16-32].

\section{Conclusions}

1. In the general structure of occupational traumatism of members of vessel's crew of the Northern water basin, various damages during the mooring of vessels account for $10.1 \%$ of cases.

2. The risk of mooring injuries is greatest in the transport river and sea fleets among sailors with production experience of up to 1 year of work in the specialty.

3. Mooring injuries are characterized by the predominance of severe bruises, deep wounds and traumatic amputations of the phalanges of the fingers.

4. The average period of incapacity for work with mooring injuries is 48.0 working days, the hospital bed for hospitalization in the surgical department - 20.6.

5. Returned to professional work after rehabilitation for mooring injuries, $94.0 \%$ of the victims of members of vessel's crew. The initial exit of victims to the II group of disability was $1.3 \%$; Group III $-2.2 \% ; 2.5 \%$ of mooring injuries were fatal.

\section{Acknowledgments}

The authors express sincere love to their parents. The authors are grateful to Bychikhin N.P., Orlov G.A., Kucherenko V.Z., Kudrina V.G., Zhuravlev S.M., Korotkikh R.V., Lindenbraten A.L., Zabin Yu.L., Novikov P.E., Siburina T.A., Dobrodeeva L.K., Kuznetsova M.N., Klepikova R.A., Udalova L.S., Smolnikov L.A., Pyankov S.M., Pisarenko E.F., Ternovsky L.N., Batygina N.I., Rzhevskaya V.N., Duberman L.B., Luss E.A., Akhmeev V.N., Schumacher R.E. and to all anonymous reviewers for their support, valuable advice, and helpful comments.

\section{References}

1. Sharapov VI (1972) Preduprezhdenie proizvodstvennogo travmatizma na rybopromyslovyh sudnah. Kaliningrad. (In Russian)

2. Timohov SA (1970) Travmatizm pri shvartovke na sudnah torgovogo flota Severnogo morskogo parohodstva. Materialy IV Vsesoyuz konf po gigiene vodnogo transporta, g. Gor'kij, 11-13. (In Russian)

3. Timohov SA (1973) Travmy pri shvartovke korablej. Ortoped. Travmatol Protez 10: 72-73. (In Russian)

4. Lukash AA (1961) O povrezhdeniyah stal'nymi trosami. Tezisy dokl k XI rasshirennoj konf Leningr obshchestva sudebnyh medikov i kriminalistov nauch. sessii In-ta Sud Mediciny MZ SSSR 27-30: 133-134. (In Russian)

5. Lukash AA (1962) K harakteristike povrezhdenij stal'nymi trosami i yakor'cep'yu. Sud-Med Ekspertiza 5: 53-54. (In Russian)

6. Timohov SA (1968) Povrezhdeniya stal'nym trosom u moryakov. Sov Medicina 10: 132-135. (In Russian)

7. Budrin YuP (1969) Smertel'nye povrezhdeniya trosami na predpriyatiyah morskogo promysla. Sud-Med Ekspertiza 12: 44-46. (In Russian)

8. Volkov VV (1969) Smertel'nye povrezhdeniya trosami u rybakov. Sud-Med Ekspertiza 12: 46-47. (In Russian)

9. Timohov SA (1965) Travmy trosom u moryakov pri shvartovke. Materialy III Arhangel'skoj obl. Travmatol konf. Arhangel'sk 22-23. (In Russian)

10. Shapovalov KA (1998) Medical and social justification of trauma care floating crew: Dissertation for the degree of Doctor of Medical Sciences / Shapovalov Konstantin Albertovich, Research-and-production Association «Medico-social Studies, Economics and Informatics» of the Ministry of Health of the Russian Federation. Moscow:117-120. (In Russian)

11. Shvartovye i buksirnye ustrojstva. Link: https://bit.ly/2TOhLVJ

12. Shapovalov KA (1986) Injuries during mooring operations on board ship. Voen Med Zh 48-49. Link: https://bit.ly/3er9nmV

13. Shapovalov KA (2003) Medical and social problems of traffic accidents floating crew on transport, river, fishing fleets. Organization of emergency trauma care on ships: monograph. - $2^{\text {nd }}$ ed., Rev. and enlarged. Syktyvkar 5658. (In Russian)

14. Kak shvartuyutsya korabli. Link: https://bit.ly/2TLPUpf 
15. Shvartovye operacii. Link: https://bit.ly/36BxA7v

16. Shapovalov KA (1986) Injuries During Mooring. Rybak Severa (Arkhangelsk occupational association of the fishing industry, Arkhangelsk, Arkhangelsk Region) (In Russian).

17. Shapovalov KA (1986) Injuries During Mooring. Rybak of Lithuania (Lithuanian occupational association of the fishing industry). (In Russian)

18. Shapovalov KA (1986) Caution During Mooring. Rechnik Severa (Northern River Shipping Company, Arkhangelsk, Arkhangelsk Region). (In Russian)

19. Shapovalov KA (1986) Injuries During Mooring Operations on Ships. Zarja Rybaka (Rostov Scientific - Occupational Association of Fisheries) (In Russian).

20. Shapovalov KA (1986) Be Careful and Cautious. Rybak of Latvia (Latvian Fisheries Production Association and the Union of Collective Fisheries Latvian SSR) (In Russian)

21. Shapovalov KA (1986) Injuries During Mooring Operations on Ships. Bolshaja Kama (Kama River Shipping Company) (In Russian).

22. Shapovalov KA (1986) Injuries During Mooring Operations on Ships. Morjak of Estonia (Estonian Shipping Company) (In Russian).

23. Shapovalov KA (1986) Injuries During Mooring Operations on Vessels. Soviet Tanker (Middle Volga Shipping Company "Volgotanker") Voen Med Zh 48-49. Link: https://bit.ly/3gwvdY8

24. Shapovalov KA (1986) Injuries During Mooring Operations. Morjak of Lithuania (Lithuanian Shipping Company) Jun 19. (In Russian)
25. Shapovalov KA (1986) Injuries During Mooring Operations on Ships. Rybak of Estonia (Estonian occupational association of the fishing industry). (In Russian)

26. Shapovalov KA (1986) Injuries During Mooring Operations on Ships. Rechnik of Sukhona (Sukhonskaja Shipping Company) (In Russian)

27. Shapovalov KA (1986) Be Ware of Mooring. Majak (Kaliningrad production association of the fishing industry) (In Russian)

28. Shapovalov KA (1986) Injuries During Mooring. Rybak of Kamchatka (Kamchatka Fishing Industry Production Association) Jul 2. (In Russian)

29. Shapovalov KA (1986) Injuries During Mooring. Rechnik of Amur (Amur River Shipping Company) Jul 23. (In Russian)

30. Shapovalov KA (1986) Mooring Injuries on Ships. Rechnik of Moldova (Office of the River Fleet of the Moldavian SSR) Aug 13. (In Russian).

31. Shapovalov KA (1986) Injuries During Mooring Operations on Vessels. Rechnik of Vjatka (Vyatskaja Shipping Company). (In Russian).

32. Shapovalov K, Shapovalova P (2019) Prevention of traumatism to the members of vessel's crew of the marine transport fleet of the Northern water basin as a form of implementation of the state policy of Russia at the new stage of development of the Northern Sea Route. ORGZDRAV: novosti, mneniya obuchenie. Tezisy VII Mezhdunarodnogo kongressa "ORGZDRAV-2019. Effektivnoe upravlenie medicinskoj organizaciej”. Chast 5: 78-79. Link: https://bit.ly/3daW61v

\section{Discover a bigger Impact and Visibility of your article publication with} Peertechz Publications

\section{Highlights}

* Signatory publisher of ORCID

* Signatory Publisher of DORA (San Francisco Declaration on Research Assessment)

* Articles archived in worlds' renowned service providers such as Portico, CNKI, AGRIS, TDNet, Base (Bielefeld University Library), CrossRef, Scilit, J-Gate etc.

* Journals indexed in ICMJE, SHERPA/ROMEO, Google Scholar etc.

* OAI-PMH (Open Archives Initiative Protocol for Metadata Harvesting)

* Dedicated Editorial Board for every journal

* Accurate and rapid peer-review process

* Increased citations of published articles through promotions

* Reduced timeline for article publication

Submit your articles and experience a new surge in publication services (https://www.peertechz.com/submission).

Peertechz journals wishes everlasting success in your every endeavours.

Copyright: @ 2020 Shapovalov KA, et al. This is an open-access article distributed under the terms of the Creative Commons Attribution License, which permits unrestricted use, distribution, and reproduction in any medium, provided the original author and source are credited. 